\title{
Looking back, thanking authors and reviewers, and envisioning the future of RevSALUS
}

\author{
Ricardo Jorge Dinis-Oliveira ${ }^{1,2,3^{*}}$ (D), Márcia Pereira4 ${ }^{\text {iD }}$, António Almeida-Dias ${ }^{5}$, Jorge Conde ${ }^{6}$ (D) \\ 'TOXRUN - Unidade de Investigação em Toxicologia, Instituto Universitário de Ciências da Saúde (IUCS), CESPU, Portugal; \\ 2Departamento de Ciências da Saúde Pública e Forenses e Educação Médica, Faculdade de Medicina, Universidade do Porto, Porto, Portugal; \\ ${ }^{3}$ UCIBIO, Laboratório de Toxicologia, Departamento de Ciências Biológicas, Faculdade de Farmácia, Universidade do Porto, Portugal; \\ ${ }^{4}$ Rede Académica das Ciências da Saúde da Lusofonia - RACS, Coimbra, Portugal; \\ ${ }^{5}$ Cooperativa de Ensino Superior Politécnico e Universitário - CESPU, Gandra, Paredes, Portugal; \\ ${ }^{6}$ Escola Superior de Tecnologia da Saúde de Coimbra - Instituto Politécnico de Coimbra - IPC, Coimbra, Portugal. \\ *Autor correspondente/Corresponding author: ricardo.dinis@iucs.cespu.pt
}

Recebido/Received: 14-01-2022; Revisto/Revised: 15-01-2022; Aceite/Accepted: 18-01-2022

\section{Resumo}

É no início do percurso científico para 2022 da RevSALUS - Revista Científica Internacional da Rede Académica das Ciências da Saúde da Lusofonia, que olhamos o passado, agradecemos os contributos e perspetivamos o futuro. Durante o ano de 2021, a RevSALUS recebeu através da sua plataforma eletrónica de gestão do processo editorial Open Journal System um total de 68 artigos, dos quais 19 foram aceites para publicação, correspondendo a uma taxa de aceitação de aproximadamente $28 \%$. É já uma grande prova de maturidade científica e da afirmação na Lusofonia. Queremos dar agora passos de gigantes na indexação às mais prestigiadas bases das ciências da saúde e da vida.

\section{Abstract}

It is in the beginning of the scientific trajectory for 2022 of RevSALUS - International Scientific Journal of the Academic Network of Health Sciences in Lusophony that we look back, thank the contributions, and look forward to the future. During the year 2021, RevSALUS received through its electronic platform of management of the editorial process Open Journal System a total of 68 articles, of which 19 were accepted for publication, corresponding to a rate of acceptance of approximately $28 \%$. It is already a great proof of scientific maturity and affirmation in Lusophony. We now want to take giant steps in the indexation to the most prestigious bases of health and life sciences.

A RevSALUS - Revista Científica Internacional da RACS verificou um aumento no volume de submissões rececionadas ao longo do ano de 2021, com uma submissão de Angola, seis submissões do Brasil, duas submissões de Moçambique e 58 submissões de Portugal.

A tarefa de decidir quais os trabalhos com mérito científico para publicação é um processo complexo. Neste âmbito, a colaboração dos especialistas, investigadores, académicos e outros profissionais a quem solicitámos a avaliação dos trabalhos propostos para publicação foi fundamental.

A RevSALUS é uma revista que promove a divulgação da produção científica junto de mais de 550 instituições de ensino superior, entidades governamentais e diplomáticas, unidades de saúde, de todos os países da lusofonia, podendo atingir um público-alvo de mais de meio milhão de estudantes e cerca de 45.000 docentes e investigadores, neste espaço internacional, através da sua divulgação em suporte digital.

Para o sucesso da RevSALUS é imprescindível o contributo de especialistas das várias áreas, que nos apoiam na identificação dos temas de maior relevância, os quais comentam a pertinência dos estudos propostos e realçam as linhas inovadoras das metodologias apresentadas.

O ano de 2021 marcou de forma evidente a trajetória de
RevSALUS - RACS International Scientific Journal registered an increase in the volume of submissions received over the year 2021, with one submission from Angola, six submissions from Brazil, two submissions from Mozambique and 58 submissions from Portugal.

The task of deciding which manuscripts have scientific merit for publication is a complex process. In this regard, the collaboration of experts, researchers, academics, and other professionals who were asked to review the submitted articles for publication was fundamental.

RevSALUS is a journal that promotes the dissemination of scientific production to more than 550 higher education institutions, governmental and diplomatic entities, health units from all Portuguese-speaking countries, reaching a target audience of more than half a million students and about 45,000 teachers and researchers, in this international space, facilitated by its dissemination in digital format.

Aiming the success of RevSALUS the contribution of specialists from the various areas is crucial. They support the editorial board in identifying the most relevant scientific topics, commenting on the pertinence of the studies proposed and highlighting the innovative lines and methodologies for research.

The year 2021 clearly marked the trajectory of growth and recognition of RevSALUS as an international scientific journal of 
crescimento e reconhecimento da RevSALUS enquanto revista científica internacional da Lusofonia, nomeadamente:

I. Iniciou a publicação contínua dos artigos e publicou o seu primeiro número bilingue português-inglês, em formato online;

II. Passou a estar integrada nas bases de dados da EBSCO;

III. Foi escolhida para acolher e publicar a seleção dos melhores artigos apresentados na $1^{\text {a }}$ Conferência Lusófona de Terapia Ocupacional, encontro realizado em suporte digital no dia 09 de julho de 2021 e organizado pelo Núcleo Académico de Terapia Ocupacional da RACS (NATO - RACS).

A realização da $4^{a}$ Reunião Internacional da RACS em Benguela, Angola, nos dias 25 a 27 de novembro de 2021, teve como ponto de destaque a submissão de mais de 400 resumos nas diversas áreas das ciências da saúde dos quais, após o escrutínio por uma Comissão Científica, foram aceites 365 trabalhos científicos na forma de comunicações orais e pósteres, que integram o Suplemento № 3 da RevSALUS.

O Conselho Editorial desta revista contou ainda com a inclusão de um novo Coeditor para a área das Ciências Farmacêuticas, o Prof. Dr. Rafael Scorsatto Ortiz da Universidade Federal do Rio Grande do Sul (Brasil).

A aquisição do serviço Publons Reviewer Recognition tem garantido uma melhoria na qualidade e eficiência do processo de reconhecimento da revisão por pares dos artigos avaliados pela RevSALUS.

Para 2022 temos ainda como grande objetivo melhorar os layouts gráficos dos nossos artigos aproximando-os das melhores editoras internacionais.

Nesta nota final gostaríamos de apelar à submissão de trabalhos científicos de enorme qualidade e à inscrição de novos revisores na plataforma, para que possamos diminuir os tempos de decisão das submissões. A inscrição pode ser feita rapidamente nesta página.

A todos e a cada um de vós que de forma rigorosa e integra demonstram reconhecer o valor do peer-review no processo científico, independentemente se o artigo veio ou não a ser publicado, e a todos os autores que contribuíram com publicações de elevada qualidade se dirige o sincero agradecimento do Conselho Editorial da RevSALUS.

A seguinte lista enumera os revisores que, ao longo do ano de 2021, procederam à avaliação de artigos e a estes muito queremos penhoradamente agradecer.

\section{Revisores com quatro avaliações concluídas:}

Carlos Pires Magalhães (Portugal)

Mariana Midori Sime (Brasil)

Marina Di Napoli Pastore (Moçambique)

\section{Revisores com três avaliações concluídas:}

Ana Maria Galvão (Portugal)

Emanuel Oliveira (Portugal)

Filipa Campos (Portugal)

Giovanna Bardi (Brasil)

Inês Pádua (Portugal)
Lusophony:

I. It started the continuous publication of articles and published its first bilingual Portuguese and English issue online;

II. It was integrated in the EBSCO database;

III. It was chosen to host and publish the selection of the best papers presented at the 1st Lusophone Conference of Occupational Therapy, a meeting held in digital support on 09 July 2021 and organized by the Academic Nucleus of Occupational Therapy of RACS (NATO - RACS).

The 4th International Meeting of RACS occurred in Benguela, Angola, from 25 to 27 November 202. It worth to be highlight that the event received the submission of more than 400 abstracts in various areas of health sciences from which, after scrutiny by a Scientific Committee, 365 scientific abstracts were accepted in the form of oral communications and posters, which will integrate Supplement No. 3 of RevSALUS.

The Editorial Board of this journal also included a new coeditor for the area of Pharmaceutical Sciences, Prof. Dr. Rafael Scorsatto Ortiz from the Federal University of Rio Grande do Sul (Brazil). The acquisition of the Publons Reviewer Recognition service has ensured an improvement in the quality and efficiency of the peer review recognition process of the articles under evaluation by RevSALUS.

For 2022 our major objective is to improve the graphic artworks layouts of our articles, bringing them closer to the best international publishers.

In this final note we would like to appeal for the submission of scientific papers of enormous quality and the registration of new reviewers on our webpage, thus we can decrease the decision times of submissions.

The Editorial Board of RevSALUS also aim to express our sincere gratitude to everyone who rigorously and fully acknowledge the value of peer-review in the scientific process, regardless of whether the article has been published.

The following section lists the reviewers who, during 2021, evaluated the articles and to whom we would like to express our deepest gratitude.

\section{Reviewers with four completed evaluations:}

Carlos Pires Magalhães (Portugal)

Mariana Midori Sime (Brazil)

Marina Di Napoli Pastore (Mozambique)

\section{Reviewers with three completed evaluations:}

Ana Maria Galvão (Portugal)

Emanuel Oliveira (Portugal)

Filipa Campos (Portugal)

Giovanna Bardi (Brasil)

Inês Pádua (Portugal)

Isabel Monteiro (Portugal)

Mariana Brito da Cruz (Portugal)

Natália Campelo (Portugal)

Raquel Simões de Almeida (Portugal)

Ricardo Lopes Correia (Brazil) 
Isabel Monteiro (Portugal)

Mariana Brito da Cruz (Portugal)

Natália Campelo (Portugal)

Raquel Simões de Almeida (Portugal)

Ricardo Lopes Correia (Brasil)

Susana Arranhado (Portugal)

\section{Revisores com duas avaliações concluídas:}

Alexandre Nunes (Portugal)

Ana Escoval (Portugal)

Bruno Vieira de Melo (Portugal)

Catarina Tomás (Portugal)

Daniel Caldeira (Portugal)

Jaime Ribeiro (Portugal)

João Longo (Portugal)

Lina Cabaço (Portugal)

Maria João Trigueiro (Portugal)

Marlene Rosa (Portugal)

Mónica Maia (Portugal)

Nuno Cordeiro (Portugal)

Nuno Morais (Portugal)

Patrícia Manarte-Monteiro (Portugal)

Patrícia Paquete (Portugal)

Rui Pimenta (Portugal)

Susana Isabel Mendes Pinto (Portugal)

\section{Revisores com uma avaliação concluída:}

Ana Leonor Alves Ribeiro (Portugal)

André Rinaldo Fukushima (Brasil)

Beatriz Minghelli (Portugal)

Beatriz Prado Pereira (Brasil)

Brígida Gimenez Carvalho (Portugal)

Carlos Sequeira (Portugal)

Catarina Godinho (Portugal)

Celeste Antão (Portugal)

David Tomé (Portugal)

Eliane Dallegrave (Brasil)

Gabriela Brochado (Portugal)

Helena Sousa (Portugal)

João Caramês (Portugal)

João Leote (Portugal)

João Moita (Portugal)

João Páscoa Pinheiro (Portugal)

José João Mendes (Portugal)

José Mesquita-Bastos (Portugal)

José Sousa (Portugal)

Lígia Monterroso (Portugal)

Liliana Grenho (Portugal)

Margarida Serrano (Portugal)

Maria da Graça Vinagre (Portugal)

Maria da Lapa Rosado (Portugal)

Marta Rosa (Portugal)

Nilza Nogueira (Portugal)

Patrícia Meireles Graça (Portugal)

Paula Santos (Portugal)

Paulo Jorge Palma (Portugal)

Pierre Michel Dugailly (Bélgica)

Renata P. Limberger (Brasil)

Ricardo Faria Almeida (Portugal)
Susana Arranhado (Portugal)

Reviewers with two completed evaluations:

Alexandre Nunes (Portugal)

Ana Escoval (Portugal)

Bruno Vieira de Melo (Portugal)

Catarina Tomás (Portugal)

Daniel Caldeira (Portugal)

Jaime Ribeiro (Portugal)

João Longo (Portugal)

Lina Cabaço (Portugal)

Maria João Trigueiro (Portugal)

Marlene Rosa (Portugal)

Mónica Maia (Portugal)

Nuno Cordeiro (Portugal)

Nuno Morais (Portugal)

Patrícia Manarte-Monteiro (Portugal)

Patrícia Paquete (Portugal)

Rui Pimenta (Portugal)

Susana Isabel Mendes Pinto (Portugal)

Reviewers with one completed evaluation:

Ana Leonor Alves Ribeiro (Portugal)

André Rinaldo Fukushima (Brazil)

Beatriz Minghelli (Portugal)

Beatriz Prado Pereira (Brazil)

Brígida Gimenez Carvalho (Portugal)

Carlos Sequeira (Portugal)

Catarina Godinho (Portugal)

Celeste Antão (Portugal)

David Tomé (Portugal)

Eliane Dallegrave (Brazil)

Gabriela Brochado (Portugal)

Helena Sousa (Portugal)

João Caramês (Portugal)

João Leote (Portugal)

João Moita (Portugal)

João Páscoa Pinheiro (Portugal)

José João Mendes (Portugal)

José Mesquita-Bastos (Portugal)

José Sousa (Portugal)

Lígia Monterroso (Portugal)

Liliana Grenho (Portugal)

Margarida Serrano (Portugal)

Maria da Graça Vinagre (Portugal)

Maria da Lapa Rosado (Portugal)

Marta Rosa (Portugal)

Nilza Nogueira (Portugal)

Patrícia Meireles Graça (Portugal)

Paula Santos (Portugal)

Paulo Jorge Palma (Portugal)

Pierre Michel Dugailly (Belgium)

Renata P. Limberger (Brazil)

Ricardo Faria Almeida (Portugal)

Ricardo Faria Almeida (Portugal)

Ricardo Ribeiro (Portugal)

Ricardo Ribeiro (Portugal)

Rui Gonçalves (Portugal)

Rui Pedro Gomes Pereira (Portugal) 


\section{Editorial}

Ricardo Faria Almeida (Portugal) Ricardo Ribeiro (Portugal)

Ricardo Ribeiro (Portugal)

Rui Gonçalves (Portugal)

Rui Pedro Gomes Pereira (Portugal)

Sandra Gavinha (Portugal)

Victor Manuel da Purificação de Castro (Portugal)
Sandra Gavinha (Portugal)

Victor Manuel da Purificação de Castro (Portugal) 